\title{
VARIABILIDADE GENÉTICA EM POPULAÇÕES NATURAIS DE Maytenus ilicifolia POR MEIO DE MARCADORES RAPD
}

\author{
GENETIC VARIABILITY OF MaytenUs ilicifolia NATURAL POPULATIONS \\ THROUGH RAPD MARKER
}

\author{
Juliana Vitoria Messias BITTENCOURT \\ Orientadora: Professora Dra Marguerite Germaine Ghislaine QUOIRIN (Departamento de Botânica - UFPR)
}

\begin{abstract}
RESUMO
Maytenus ilicifolia é um arbusto de ocorrência natural da Floresta Ombrófila Mista (Floresta com Araucária). Esta espécie tem uso popular em comunidades tradicionais e povos indígenas no Brasil. A fragmentação da Floresta com Araucária, nas últimas décadas, juntamente com a comprovação terapêutica em males gástricos e o uso em larga escala, causaram grande devastação de populações naturais de Maytenus ilicifolia, resultando na perda do complexo genético deste recurso medicinal. Há necessidade urgente de estudos para elaborar estratégias de conservação genética e domesticação deste germoplasma. O objetivo deste estudo foi determinar a variabilidade genética em populações naturais Maytenus ilicifolia por meio da análise do polimorfismo de DNA utilizando marcadores RAPD. Três populações foram estudadas, uma no município da Lapa e duas na região de Guarapuava. Estas áreas são distintas, tanto geologicamente quanto em relação a paisagem.

bandas em Maytenis ilicifolia, sendo 44 polimórficas. A análise da distância genética foi realizada pelo agrupamento das amostras segundo os princípios da taxonomia numérica, utilizando-se o coeficiente de similaridade de Jaccard. A partir das distâncias genéticas, montou-se um dendrograma, o qual separou o material estudado em quatro grupos distintos, dois para a região da Lapa e dois para Guarapuava. Os grupamentos formados estão arranjados de acordo com as características geológicas e classes de solos em que os indivíduos se encontram. A variabilidade genética das populações de Guarapuava, quando comparada a da Lapa, apresentou uma maior similaridade entre os grupos formados. Estratégias para conservação genética em Maytenus ilicifolia devem ser estruturadas de acordo com os parâmetros ecogeográficos locais, realizando a coleta em cada um dos compartimentos ambientais em que os indivíduos se encontram.
\end{abstract} Selecionou-se sete primers RAPD, os quais produziram 52

\begin{abstract}
Maytenus ilicifolia is a shrub with natural occurrence from Ombrophilous Mixed Forest (Araucaria Forest). This species is used by Brazilian indigenous and local people for stomachs illness. The fragmentation of the Araucaria Forest together with the therapeutic comprovation and use in large scale of Maytenus ilicifolia had caused big devastation of natural populations. This resulted in lost of genetic complex of this medicinal resources. It is urgent to elaborate strategies of genetic conservation and domestication of this germplasm. The goal of this study was to determine the genetic variability in natural populations of Maytenus ilicifolia through DNA polymorphism using RAPD markers. Three populations were studied, one in Lapa city and two in Guarapuava region. These areas have different geology and landscape

produced 52 markers in Maytenus ilicifolia, 44 of them were polymorphic. The genetic distance analysis was made by pair-group of the samples following the numerical taxonomy and using the similarity cofficient of Jaccard. With the genetic distance was made a dendrograme, which separated them in four main groups, two for the region of Lapa and two for Guarapuava. The groups were following flue geological characteristics and soil groups where the plants were growing. The genetic variability of Guarapuava populations, when compared with Lapa, show as a large similarity among their groups. Strategies for genetic conservation of Maytenus ilicifolia should be desing following the local ecogeographic parameters, collecting samples in each environmental compartment.
\end{abstract} characteristics. Seven RAPD primers were selected, which 